\title{
A comparison of bee bread made by Africanized and European honey bees (Apis mellifera) and its effects on hemolymph protein titers
}

\author{
Gloria DeGrandi-Hoffman ${ }^{1}$, Bruce J. Eckholm ${ }^{2}$, Ming Hua Huang ${ }^{2}$ \\ ${ }^{1}$ Carl Hayden Bee Research Center, USDA-ARS, 2000 East Allen Road, Tucson, AZ 85719, USA \\ ${ }^{2}$ Department of Entomology, University of Arizona, Tucson, AZ 85721, USA
}

Received 30 January 2012 - Revised 29 May 2012 - Accepted 19 June 2012

\begin{abstract}
The influence of genotype on the conversion of pollen to bee bread and on the protein titers of bees feeding on it was examined using European and Africanized honey bees (EHB and AHB). Bee bread was more acidic than the pollen, and that made by EHB was slightly more acidic than AHB. Protein concentration in bee bread was similar for both subspecies and lower than in the pollen. In general, amino acid concentrations were higher in bee bread compared with pollen. The only exception was tryptophan. Concentrations of most amino acids in bee bread made by either EHB or AHB were similar. Both subspecies consumed more bee bread made by AHB than EHB. EHB and AHB consumed similar amounts of each type of bee bread, but protein concentrations in AHB were higher than in EHB. Differences in protein acquisition between AHB and EHB might reflect environmental adaptations related to the geographic region where each evolved and could contribute to the successful establishment of AHB populations in the New World.
\end{abstract}

nutrition / microbes / protein / amino acids

\section{INTRODUCTION}

Nutrition plays a fundamental role in the health and vigor of honey bee colonies and in their establishment as populations. Nutrients from food provide energy and the biochemical components needed for brood rearing, thermoregulation, foraging and immune response. For honey bee colonies, the nutrients needed to grow colony populations and maintain their health come from nectar and pollen. Nectar provides carbohydrates and pollen supplies the remaining dietary requirements such as protein, lipids, vitamins, and minerals (see Brodschneider and Crailsheim 2010).

Corresponding author: G. DeGrandi-Hoffman, Gloria.Hoffman@ARS.USDA.GOV

Manuscript editor: Stan Schneider
Subspecies of honeybees can differ in nutritionally based colony-level parameters such as worker longevity, brood rearing, and mechanisms of social immunity (Spivak 1992; Schneider and McNally 1993; Becerra-Guzman et al. 2005; Saltykova et al. 2005; Decanini et al. 2007). These differences might be linked to how food, particularly pollen, is processed by the colony and digested in individuals. Pollen is stored in comb cells and through microbially mediated lactic acid fermentation (Gilliam 1979a, b; Gilliam et al. 1989) is chemically changed (Loper et al. 1980). The fermented pollen is called bee bread. There might be genotypic differences among subspecies in their ability to acquire nutrients from the pollen they collect and store and this could affect colony growth and survival. Genotypic effects on food processing and nutrient acquisition have been 
documented in other organisms (e.g., Khachatryan et al. 2008), causing some individuals to obtain more nutrients and calories than others while consuming the same foods (Turnbaugh et al. 2006; Ley et al. 2005, 2006). Accumulating evidence suggests that the gut microbiota plays an important role in nutrient acquisition from food (Krajmalnik-Brown et al. 2012), and that host genotype can have a tremendous effect on the diversity and population structure of the microbiota (Spor et al 2011). In honey bees, how genotype affects nutrient acquisition from pollen either through the fermentation process or digestion in individuals is unknown.

Previous studies on the composition and nutritive value of bee bread were done with European honey bees (EHB) (e.g., Standifer et al. 1980; Loper et al. 1980; Human and Nicolson 2006). However, there may be differences in the composition and consumption of bee bread made by bees of different subspecies even when they feed on the same pollen. We addressed this question by presenting the same pollen to Africanized honey bees (AHB) and EHB and then comparing the consumption and the protein and amino acid composition of the bee bread produced by each subspecies. We chose these subspecies because EHB and AHB have distinct behavioral and physiological differences that might be related to food processing and nutrient acquisition. Some of the most notable are that AHB collect and consume more pollen than EHB and seem to convert it more readily into brood (Winston 1992). AHB colonies have higher swarming rates than EHB and abscond when food resources become limited (Woyke 1976, 1977; Winston et al. 1979; Schneider and McNally 1992a; Hepburn et al. 1999). Absconding is rare in EHB. AHB also have higher metabolic rates than EHB (Harrison et al. 2006).

The nutritional basis for the colony-level differences between EHB and AHB might be related to the rate of pollen collection and also to its nutrient content (e.g., amino acids and protein) after it is converted to bee bread. Bee bread consumption and the resulting protein acquisition also might play a role in the colony- level differences between EHB and AHB. In this study, we fed bee bread made by EHB and AHB to both subspecies of bees. Thus, we could determine if bees acquire protein from bee bread at rates that are distinctive to their subspecies or to the source of the bee bread.

\section{METHODS AND MATERIALS}

All EHB used in the study were Italian bee (Apis mellifera ligustica) colonies headed by commercially produced and mated European queens (Koehnen and Sons Inc., Glenn, California). The AHB were captured from swarms in Tucson, AZ, USA. Southern Arizona has an established feral population of Africanized bees that originated from the northward expansion of Africanized populations following the introduction of $A$. mellifera scutellata into Brazil (Fewell and Bertram 2002; Schneider et al. 2004a; Rabe et al. 2005). Africanization of the bees used in this study was confirmed using mitochondrial DNA (Nielsen et al. 2000) and morphometric analyses (Rinderer et al. 1993). All source colonies for this study were maintained in apiaries at the Carl Hayden Bee Research Center in Tucson, AZ, USA. Tucson is located in the Sonoran Desert and has an arid climate with annual precipitation usually less than $40 \mathrm{~cm}$.

\subsection{Obtaining frames of bee bread from Africanized and European colonies}

Five colonies each of $\mathrm{EHB}$ and $\mathrm{AHB}$ were used to make bee bread. Each EHB or AHB colony was comprised of five frames of adult bees and unsealed brood (about 3,500-4,000 adult bees per colony). The colonies were placed in an enclosed flight area (EFA) at the Carl Hayden Bee Research Center in Tucson, AZ, USA. The EFA is separated into 10 sections. Bees cannot forage outside the enclosure or cross between sections. One colony (either EHB or AHB) was placed in each of the 10 sections so that five sections contained EHB and five contained AHB. The colonies had no pollen stores when we established them in the enclosure but did contain open brood and some nectar and honey. Empty frames were placed in the colonies to provide space for the bees to store pollen. These colonies were used only to make bee bread with the pollen we provided. 
The pollen we provided was a polyfloral mixture collected by colonies in apiaries in the Sonoran Desert in Arizona, USA. The pollen was collected less than 6 months before the study and kept frozen until fed to the bees. The pollen was fed in powdered form. Prior to feeding the pollen to the bees, it was analyzed for pesticides and fungicides by the USDAAMS National Science Laboratory in Gastonia, NC, USA. The pollen was free of contaminants (data not shown). We took six samples of the pollen for protein and amino acid analysis. All pollen samples were kept at $-20{ }^{\circ} \mathrm{C}$ until analyzed.

Pollen was provided to the colonies on trays in each section of the EFA. The bees collected the pollen on their hind legs as corbicular loads and stored it in cells. The bee bread was produced during a 3-week period and was used to feed a separate group of worker bees in cages. Bee bread from the European colonies is hereafter referred to as European bee bread (EBB) and from Africanized colonies as Africanized bee bread (ABB).

\subsection{Feeding bees in cages}

Cages containing 100 newly emerged EHB or AHB worker bees were established for each of the following treatment combinations: $\mathrm{AHB}$ fed $\mathrm{ABB}$, EHB fed ABB, AHB fed EBB, and EHB fed EBB. There were six cages for each treatment combination. The bees for the cages came from frames of sealed worker brood that were removed from Africanized and European colonies and placed in separate emergence boxes in a climate-controlled environmental room at $32-34{ }^{\circ} \mathrm{C}$ and $70 \%$ humidity. When the workers emerged and were about $24 \mathrm{~h}$ old, they were transferred to the Plexiglas bioassay cages (dimensions $=11.5 \times 7.5 \times 16.5 \mathrm{~cm})$. One hundred workers were placed in each cage. The cages contained a section of comb with either EBB or ABB selected at random from the frames of the colonies in the EFA. Each section of comb was comprised of 24-30 cells filled to approximately the same level with bee bread. The exact number of cells in each cage was recorded prior to adding the bees. The bees in the cages also were supplied with vials of water and a $50 \%$ honey and water solution. The honey and water vials were refilled daily. The cages with the bees remained in the environmental room at $32-34{ }^{\circ} \mathrm{C}$ and $70 \%$ humidity for 11 days.

\subsection{Sampling worker bees and bee bread and estimating consumption}

Ten EHB and AHB workers were sampled from the newly emerged bees prior to placing them in the cages. These bees are referred to as day 0 bees. An additional 10 bees were removed from each cage 4,7 , and 11 days after feeding on the bee bread. The live bees were placed in individual Eppendorf tubes and set on ice packs. A subsample of four bees from the 10 collected was used for analysis of hemolymph protein concentration.

After sampling bees on day 11, the number of comb cells that still contained bee bread was counted for each cage and used as a relative measure of bee bread consumption. We chose this method because the bees stored some of the honey we fed them in the empty cells on the comb thus making changes in weight of the comb before and after feeding inaccurate. The remaining bee bread from the cells in each cage was removed and stored in separate Eppendorf tubes according to cage at $-70{ }^{\circ} \mathrm{C}$ until analyzed for $\mathrm{pH}$, soluble protein concentration, and amino acid content.

\subsection{Estimating $\mathrm{pH}$ of pollen and bee bread}

The $\mathrm{pH}$ of the pollen used to make bee bread was estimated using six random samples of the pollen used for feeding the colonies in the EFA. A sample of bee bread from each cage that remained after the 11day feeding period was used to estimate the $\mathrm{pH}$ of bee bread. We estimated the $\mathrm{pH}$ using a 0.3 -g sample of pollen or bee bread placed in a $1.5-\mathrm{ml}$ centrifuge tube (Eppendorf North America, Westbury, NY) and dissolved in $300 \mu \mathrm{l}$ of distilled water. The $\mathrm{pH}$ of the mixture was measured with a waterproof double junction $\mathrm{pH}$ spear (Thermo Fisher Scientific) with an accuracy of \pm 0.01 .

\subsection{Protein analysis}

We analyzed soluble protein concentrations in: the pollen used to make bee bread, EBB and ABB, and in the hemolymph of bees that were $0,4,7$, and 11 days old. Six samples of the pollen and a sample of EBB and $\mathrm{ABB}$ from each cage were collected and kept at 
$-20{ }^{\circ} \mathrm{C}$ until analyzed. The bees were placed in separate $1.5 \mathrm{ml}$ tubes and kept refrigerated until their hemolymph was collected 1-2 h later.

Pollen and bee bread were prepared for analysis of soluble protein concentration by mixing a $20-\mathrm{mg}$ sample with $1,000 \mu \mathrm{l}$ of phosphate buffer solution (PBS). The mixture was vortexed for $10 \mathrm{~s}$ and centrifuged at $8,500 \mathrm{rpm}$ for $1 \mathrm{~min}$. Ten-microliter samples of the supernatant were placed in wells of a 96-well flat bottom EIA/RIA polystyrene plate. Each sample was replicated in three wells.

Hemolymph from bees was drawn by inserting a $20-\mu \mathrm{L}$ capillary tube (that had been heated and pulled to a needle-sharp point) into the right lateral portion of the thorax near the point of attachment of the wings. Additional hemolymph, if needed, was collected by inserting the same tube into the membrane between the abdominal tergites. Approximately 1$5 \mu \mathrm{L}$ of hemolymph was collected in the capillary tube. Hemolymph samples were stored at $-20{ }^{\circ} \mathrm{C}$ until analysis. The samples were prepared for analysis of soluble protein concentration by adding $1 \mu \mathrm{L}$ of sample to $9 \mu \mathrm{L}$ of PBS.

Total soluble protein concentrations in pollen, bee bread, and hemolymph samples were estimated using a Quick Start Bradford Protein Assay Kit 2 (\#5000202, Bio-Rad Laboratories, Hercules, CA) (Sagili et al. 2005; Sagili and Pankiw 2007). Standard curves to estimate soluble protein concentration in the samples were prepared using bovine serum albumin. Protein absorbance was measured at $595 \mathrm{~nm}$ using a Biotek Synergy HT spectrophotometer.

\subsection{Amino acid analysis}

Amino acid analysis was conducted by MDx BioAnalytical Laboratory, Inc, (College Station, TX). A single $0.3-\mathrm{g}$ sample of pollen fed to bees and two $0.3-\mathrm{g}$ samples each of EBB and ABB were analyzed for amino acid concentrations. The bee bread samples were obtained by pooling individual samples taken from comb cells of each colony. All samples were processed and analyzed in duplicate by gas chromatography-mass spectrometry (GC/MS) following trimethylsilyl (TMS) derivatization (Gehrke and Leimer 1971). Concentrations of amino acids are expressed as microgram of each amino acid per gram of pollen or bee bread.
Amino acid concentrations were estimated using a $50-\mathrm{mg}$ pollen or bee bread sample weighed into autosampler vials; $1 \mathrm{~mL}$ of $\mathrm{H}_{2} \mathrm{O}$ was added to the vial, along with $100 \mu \mathrm{L}$ of $50 \mathrm{ng} / \mu \mathrm{L}$ of a four internal standard solution consisting of $\mathrm{d}_{4}$-alanine, $\mathrm{d}_{23}$-lauric acid, ${ }^{13} \mathrm{C}_{6}$-glucose, and $\mathrm{d}_{39}$-arachidiac acid. The sample was capped and sonicated for $5 \mathrm{~min}$. An HLB cartridge was conditioned by adding $1 \mathrm{~mL}$ of methanol, equilibrated by adding $1 \mathrm{~mL}$ of water followed by the addition of $1 \mathrm{~mL}$ of sample. The cartridge was then washed with $1 \mathrm{~mL}$ of $5.0 \%$ $\mathrm{MeOH} /$ water and eluted with $1 \mathrm{~mL}$ of $80 \% \mathrm{MeOH} /$ $\mathrm{H}_{2} \mathrm{O}$. The extract was placed into an autosampler vial and evaporated to dryness under a stream of nitrogen. Subsequently, the sample was reconstituted with $50 \mu \mathrm{L}$ of pyridine and $100 \mu \mathrm{L}$ of $N, O$-Bis(trimethylsilyl)trifluoroacetamide + trimethylchlorosilane (BSTFA + TMCS). The solution was capped and incubated at $70{ }^{\circ} \mathrm{C}$ for $30 \mathrm{~min}$. The sample was allowed to cool and then transferred to a glass insert, placed into a clean autosampler vial, and capped and placed into an Agilent 5973N Mass Selective Detector interfaced to an Agilent 6930 gas chromatograph to analyze the samples both for volatile compounds and organic acids. A J\&W Scientific DB-1701 column $(30 \mathrm{~m} \times 0.25 \mathrm{~mm}$ i.d. $)$ with a 1.0 $\mu \mathrm{m}$ film thickness was used to separate the sugar and organic acids following TMS derivatization with BSTFA + TMCS. The column oven was held at $50{ }^{\circ} \mathrm{C}$ for $2 \mathrm{~min}$, then programmed linearly to $290{ }^{\circ} \mathrm{C}$ at $5{ }^{\circ} \mathrm{C} / \mathrm{min}$ and held for $7 \mathrm{~min}$. The $\mathrm{GC}$ injector and $\mathrm{GC} / \mathrm{MS}$ interface were set to 250 and $290{ }^{\circ} \mathrm{C}$, respectively. Helium was used as a carrier for both analyses at a flow rate of $1.0 \mathrm{~mL} / \mathrm{min}$. The MS source temperature was set to $230{ }^{\circ} \mathrm{C}$. The mass spectrometer was tuned and calibrated daily with perfluorotributylamine (PFTBA). A $1-\mu \mathrm{L}$ injection of PFTBA was made and data were acquired in the full scan (35-700 amu) positive ion mode.

\subsection{Data analysis}

The $\mathrm{pH}$ of the pollen was compared with EBB and $\mathrm{ABB}$ fed to either EHB or AHB using a one-way analysis of variance. We also compared the $\mathrm{pH}$ of $\mathrm{EBB}$ and $\mathrm{ABB}$ when fed to $\mathrm{EHB}$ or AHB using a two-way analysis of variance with the type of bee bread (EBB or $\mathrm{ABB}$ ) and subspecies feeding on it 
(EHB or AHB) as factors. Bee bread consumption was estimated as the ratio of cells without bee bread after 11 days/cells with bee bread at the start of the study. Comparisons of the ratios of the bee bread consumed were made among the treatment groups using two-way analysis of variance with the same factors as those used for comparisons of $\mathrm{pH}$. The soluble protein concentration in pollen and bee bread was compared using a oneway analysis of variance followed by a Fisher's least significant difference test (LSD) multiple comparison test (Field 2005). The concentration of soluble protein in the hemolymph during the 11-day feeding period was compared among cages of the four treatment groups using a repeated measures analysis of variance followed by a Fisher's LSD test with subspecies making the bee bread and subspecies consuming it as between subject factors. A second repeated measures analysis was conducted comparing hemolymph protein levels on days 4,7 , and 11 using subspecies that made the bee bread and subspecies consuming it as between subject factors. A full factorial model was used that contained all factor main effects, all covariate main effects, and all factor-by-factor interactions. In both analyses, the concentrations of soluble protein measured in bees were summed for each cage and used as a single measurement.

\section{RESULTS}

\section{1. pH of pollen and bee bread}

EHB and AHB foragers collected the pollen we provided in the EFA, packed it in their corbiculae, and stored it in cells in their colonies. The average $\mathrm{pH}$ of the pollen we provided to the bees was $4.7 \pm 0.009$, and this was significantly higher than the ABB or EBB fed to either subspecies $(F=1,827.8, d f=4,22$, $P<0.0001)$. The $\mathrm{pH}$ of $\mathrm{EBB}$ was $3.92 \pm 0.013$ and $\mathrm{ABB}$ was $3.97 \pm 0.014$. A two-way analysis of variance comparing $\mathrm{EBB}$ and $\mathrm{ABB}$ fed to $\mathrm{EHB}$ or AHB indicated that the $\mathrm{pH}$ of bee bread was significantly affected by the subspecies of bee that made it $(F=15.43, d f=1,23, P=0.001)$ and the subspecies of bee to which it was fed $(F=$ 5.04, $d f=1,23, P=0.036)$. The interaction term (subspecies $\times$ ABB or EBB) was not significant $(F=1.97, d f=1,23, P=0.176)$.

\subsection{Consumption of bee bread}

The bees in the cages clustered on the comb containing the bee bread within minutes of putting them into the cage. In most cases, there were fewer comb cells with bee bread after the 11-day feeding interval than when the experiment began. However, one cage of each treatment did not have any cells where bee bread was completely consumed although there was evidence that bees had been feeding on the pollen and that some was removed from cells. We did not estimate bee bread consumption in these cages.

A two-way analysis of variance indicated that the amount of bee bread consumed was significantly affected by the subspecies that made it ( $F=$ 20.92, $d f=1,16, P<0.0001)$ but not the subspecies consuming it $(F=0.54, d f=1,16, P=0.47)$. The interaction term was not significant $(F=0.45$, $d f=1,16, P=0.513)$. EHB and AHB consumed similar amounts when fed the same type of bee bread but consumed significantly more ABB than EBB (Figure 1).

\subsection{Soluble protein concentration}

The average concentration of soluble protein in the pollen was $837.5 \pm 51.7 \mu \mathrm{g} / \mathrm{mL}$. The concentration in EBB fed to either EHB or AHB did not differ ( $t=0.77, d f=7, P=0.44)$ nor did the ABB fed to either subspecies $(t=0.32, d f=9, P=0.753)$. Therefore, we combined the protein measurements for each type of bee bread. EBB had a soluble protein concentration of $567 \pm 26 \mu \mathrm{g} / \mathrm{mL}$ and the $\mathrm{ABB}$ was $577 \pm 30 \mu \mathrm{g} / \mathrm{mL}$; these averages were not significantly different $(t=0.85, d f=21$, $P=0.403)$. Pollen had a significantly higher concentration of soluble protein than EBB or ABB $(F=16.49 ; d f=2,27, P<0.0001)$.

The soluble protein concentration in the hemolymph of EHB and AHB on day 0 did not differ significantly $(\mathrm{EHB}=1,125 \pm 200 \mu \mathrm{g} / \mathrm{mL}, \mathrm{AHB}=$ $787 \pm 155 \mu \mathrm{g} / \mathrm{mL} ; t=1.41, d f=9, P=0.192)$. A repeated measures analysis of variance of the average amount of soluble protein in the hemolymph during the 11-day interval indicated significant differences among the four treatment groups $(F=19.7, d f=3,20, P<0.001)$. There 


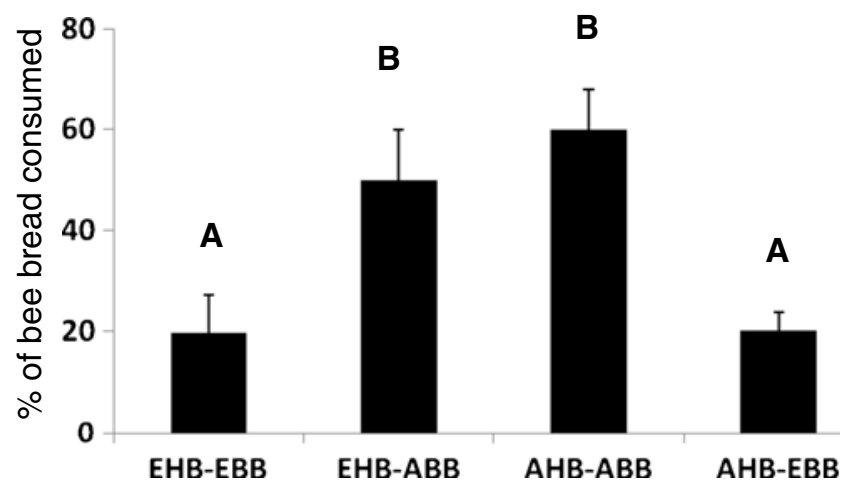

Figure 1. The average percentage of cells containing bee bread that were completely consumed over an 11-day interval by caged bees. The bee bread was made by either European $(E H B)$ or Africanized $(A H B)$ bees using the same pollen source. Bee bread made by AHB is designated as $A B B$ and by EHB as $E B B$. Means were estimated from five cages of each treatment. A two-way analysis of variance indicated that consumption was significantly affected by the race of bee making the bee bread $(F=20.92, d f=1,16, P<0.0001)$ but not the subspecies consuming it $(F=0.54, d f=1,16, P=0.47)$. The interaction term was not significant $(F=0.45, d f=1,16, P=0.513)$. Means with the same letter are not significantly different at the 0.05 level as determined by a Tukey's $W$ test.

were significant effects of the subspecies consuming the bee bread $(F=12.1, d f=1,20, P=$ $0.002)$, but not the source of bee bread (ABB or EBB) $(F=0.027, d f=1,20, P=0.87)$ or the interaction between them $(F=0.509, d f=1,20$, $P=0.48)$. Levels of soluble protein in AHB fed
$\mathrm{ABB}$ were significantly higher than $\mathrm{EHB}$ fed either $\operatorname{EBB}(P=0.018)$ or $\mathrm{ABB}(P=0.008)$ (Figure 2). When bees were fed bee bread made by the other subspecies, protein levels in AHB fed EBB were significantly higher than EHB fed ABB $(P=0.029)$. There were no

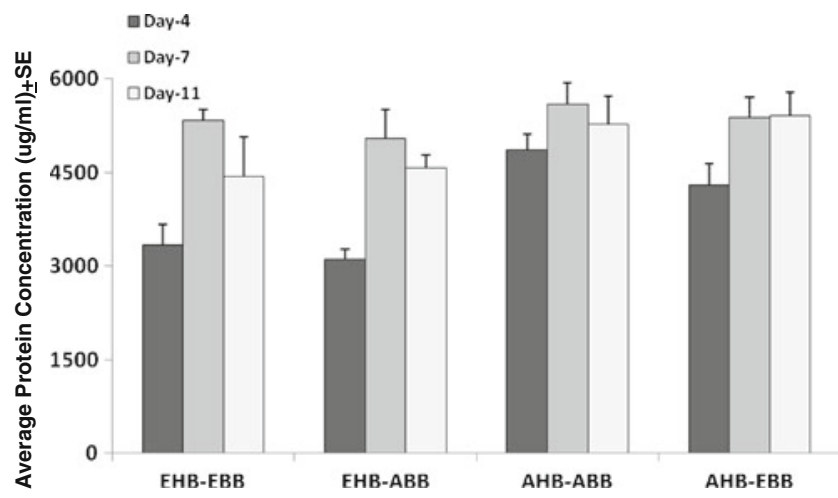

Figure 2. The average concentration of protein in hemolymph of European $(E H B)$ or African $(A H B)$ honey bees fed bee bread made by European $(E B B)$ or African $(A B B)$ bees for 4, 7, and 11 days. A repeated measures analysis of variance indicated significant differences among the four treatment groups $(F=19.7, d f=3,20, P<$ $0.001)$. There were significant effects of the subspecies consuming the bee bread $(F=12.1, d f=1,20, P=0.002)$, but not the source of bee bread (ABB or EBB) $(F=0.027, d f=1,20, P=0.87)$ or the interaction between them $(F=0.509, d f=1,20, P=0.48)$. Levels of soluble protein in AHB fed ABB were significantly higher than EHB fed ABB $(P=0.008)$ and EHB fed EBB $(P=0.018)$. The age of the bees at the time of sampling also significantly affected soluble protein concentrations in the hemolymph. Levels were significantly lower in day 4 bees compared with day $7(P<0.0001)$ or $11(P=0.001)$. Day 7 and day 11 bees did not differ $(P=0.149$.) 
differences between subspecies when they were both fed EBB $(P=0.24)$. The age of the bees at the time of sampling also significantly affected soluble protein concentrations in the hemolymph. Levels were significantly lower in day 4 bees compared with day $7(P<0.0001)$ or $11(P=0.001)$. Day 7 and day 11 bees did not differ $(P=0.149)$.

\subsection{Amino acid analysis of pollen and bee bread}

Of the 10 amino acids that are essential for honey bees, all but histidine were detected in
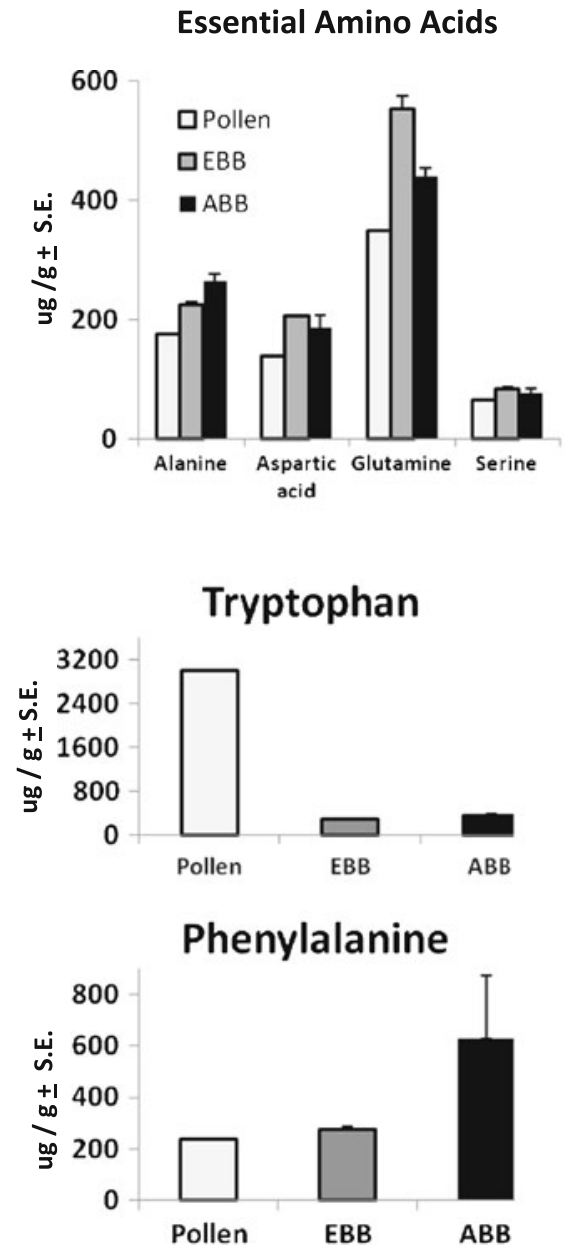

the pollen. Lysine and asparagine could not be accurately quantified in the bee bread due to interference from excess sugars. This also was the case for tyrosine in ABB. This amino acid was present in the pollen at a concentration of $198.6 \mu \mathrm{g} / \mathrm{g}$ and was quantified in one EBB sample $(160.5 \mu \mathrm{g} / \mathrm{g})$.

In most cases, amino acid concentrations measured in bee bread were higher than in the pollen (Figure 3). For example, concentrations of leucine and threonine were about $60 \%$ higher in bee bread compared with pollen, and valine concentrations were about $25 \%$ higher. Alanine, aspartic acid, and glutamine levels also

\section{Non-Essential Amino Acids}
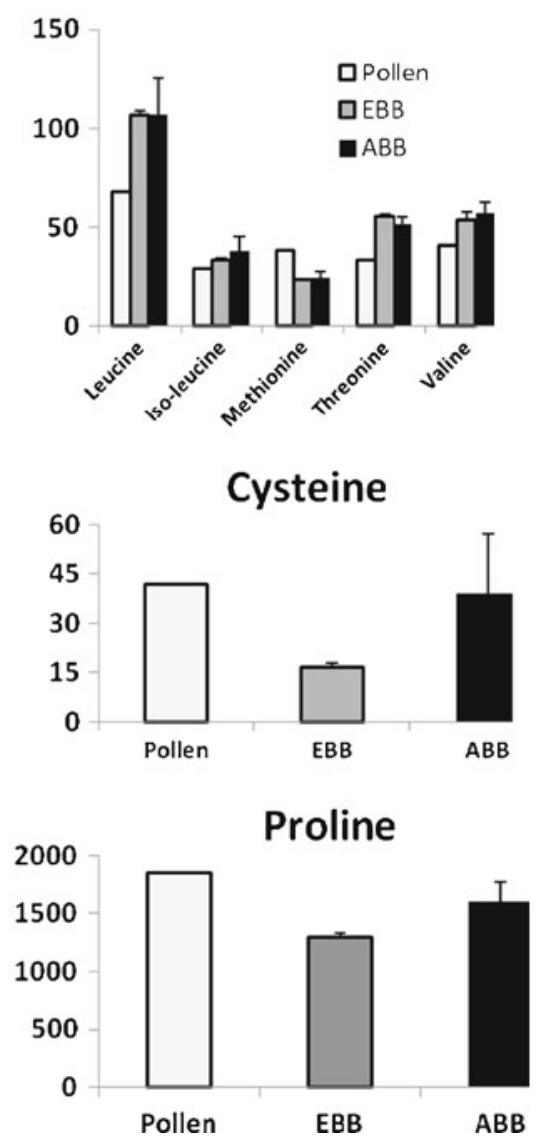

Figure 3. Concentrations of amino acids (in micrograms per gram of pollen or bee bread) in pollen or bee bread made by European $(E B B)$ or African $(A B B)$ honey bees. Tryptophan, cysteine, phenylalanine, and proline were plotted separately for purposes of clarity in presenting their amounts. 
were higher in bee bread than in pollen. Amino acid concentrations did not differ greatly between $\mathrm{ABB}$ and $\mathrm{EBB}$ with the exception of phenylalanine and cysteine. Phenylalanine levels were about twice as high in $\mathrm{ABB}$ compared with either EBB or pollen. Cysteine concentrations were lower in EBB compared with $\mathrm{ABB}$ or pollen. Tryptophan was the only amino acid present in higher concentrations in pollen than in $\mathrm{EBB}$ or $\mathrm{ABB}$. Concentrations of proline in pollen and $\mathrm{ABB}$ were higher than in EBB.

\section{DISCUSSION}

The most striking difference between the two types of bee bread was the amounts consumed and how this translated into soluble protein levels in the hemolymph. Bees of both subspecies consumed more ABB than EBB. Though both subspecies consumed similar amounts of $\mathrm{ABB}$, AHB had higher hemolymph protein titers than EHB. Protein concentrations did not differ with respect to the type and amount of bee bread they consumed within either subspecies. There appears to be a plateau for hemolymph protein concentration in each subspecies that cannot be elevated by increasing food consumption and is set higher in AHB than EHB.

The bees were able to store the pollen we provided and reduce its $\mathrm{pH}$ during the storage and conversion to bee bread. Reductions in $\mathrm{pH}$ during the conversion of pollen to bee bread have been attributed to the activity of lactic acid bacteria that are added to the pollen from the honey stomach (Loper et al. 1980; Vasquez and Olofsson 2009). We found statistically significant differences in $\mathrm{pH}$ between $\mathrm{EBB}$ and $\mathrm{ABB}$ though the differences were slight and might not have affected pollen preservation or nutrient availability. However, the differences in $\mathrm{pH}$ between $\mathrm{EBB}$ and $\mathrm{ABB}$ suggest that the composition of microbial communities in $\mathrm{ABB}$ and $\mathrm{EBB}$ might not be the same especially with regard to those synthesizing acidic compounds from metabolic activities.

The consumption of bee bread in this experiment was an approximation because the only consumption that was counted was when cells were completely emptied of bee bread. We could have estimated total bee bread consumption by removing the bee bread from the cells and weighing it before and after the study period. However, we wanted to keep the bee bread in the cells so that the bees could feed on it as they would in a colony and continue processing it if necessary during the study period. We did not use the difference in weight of the comb sections before and after the study as an estimate of consumption because bees put the diluted honey we fed them in some cells and might also have added some to the bee bread. This would have made differences in comb weights inaccurate measurements of food consumption. For these reasons, we counted cells containing approximately equal amounts of bee bread before and after the feeding period. Though our measurements were qualitative, there was a striking difference between the two types of bee bread in the number of empty ABB cells we counted compared with EBB after 11 days.

One reason that more $\mathrm{ABB}$ than $\mathrm{EBB}$ was consumed might be that concentrations of phagostimulatory compounds differed between the two types of bee bread. One such compound might be proline. There was about $20 \%$ more proline in $\mathrm{ABB}$ than $\mathrm{EBB}$. Insects can detect proline in their food and can use it as an energy substrate to fuel flight and other high energy activities (Brosemer and Veerabhadrappa 1965; Crabtree and Newsholme 1970; Carter et al. 2006). Honey bees have a feeding preference for nectars with higher concentrations of this amino acid (Carter et al. 2006; Bertazzini et al. 2010). The preference for proline might also occur in bee bread and thus increase its consumption. Further studies are needed to confirm this and identify other differences between $\mathrm{EBB}$ and $\mathrm{ABB}$ that might affect consumption rates.

The nutritional value of pollen often is evaluated by protein concentrations and the presence and amount of essential amino acids (Bonvehi and Jorda 1997; Roulston and Cane 2000). Some pollens are classified as highly nutritious while others have marginal value (see Somerville 2005). However, these nutritional 
evaluations might not be accurate. In our study, protein concentrations were higher in pollen than in bee bread, but most amino acid concentrations were lower. Similar results were reported by Human and Nicolson (2006) in a study comparing fresh, bee-collected and bee-stored pollen from Aloe greatheadii var. davyana. One way that free amino acid levels can be elevated is from the action of specific proteolytic enzymes causing cleavage at sites of particular amino acids. Alternatively, amino acids can be synthesized de novo by microbes (Metges 2000). We also found that some amino acids concentrations were lower in bee bread than in the pollen. These reductions also might be due to microbial activity since some microorganisms use amino acids as carbon and energy sources. For example, concentrations of tryptophan were lower in EBB and $\mathrm{ABB}$ compared with that in pollen. The reduction could be due to the presence of indole bacteria previously reported by Chevtchik (1950) (cited in Gilliam 1979a) that use tryptophan as an energy source. Similarly, proline concentrations were lower in EBB than in the pollen or in $\mathrm{ABB}$, and this could be due to bacteria with specific pathways to degrade amino acids (Collins et al. 1994; Fonknechten et al. 2010). Free amino acids also can be incorporated into proteins and this too would reduce their concentrations. The amino acid content of bee bread probably depends not only on the source of the pollen but perhaps the genotype of the bees processing it into bee bread. Thus, evaluating the nutritional value of pollen alone might not be as informative as considering its conversion to bee bread because nutrient concentrations can change. The role of genotype in this conversion should be further investigated.

Our findings that AHB have higher hemolymph protein levels than EHB are similar to those reported by Cappelari et al. (2009) using a different EHB subspecies: A. mellifera carnica. In that study, hemolymph protein concentrations were measured after feeding protein supplements or a mixture of bee bread (unknown source) and powdered sugar. In both studies, the AHB were from feral populations while the EHB were from domesticated lines. Protein levels in the hemolymph of AHB might differ from EHB, but there also might be differences within subspecies between managed and feral populations due to the selection pressures experienced by each. For example, managed colonies are fed with protein supplements when flowering plants are unavailable (Mattila and Otis 2006; DeGrandi-Hoffman et al. 2008), and when resources are abundant, nests are expanded by adding frames of drawn comb. Feral colonies must balance brood rearing and storage space with incoming resources. This might cause workers in feral colonies to store more resources in their own bodies than their counterparts in managed hives. Future studies should examine hemolymph protein in feral and managed EHB to determine if differences exist that might be due to domestication and management practices.

Our study might have uncovered some nutritionally based factors contributing to the immigration and successful establishment of AHB in areas with resident EHB populations. AHB collect more pollen than EHB (Winston 1992; Spivak 1992; Schneider et al. 2004a) and can attain higher hemolymph protein levels from it. This would enable colonies to rear more brood and have workers with extended adult life spans (Schultz et al. 1998; Toth et al. 2005; Toth and Robinson 2005). Together these factors will generate rapid colony growth and high rates of swarming. While some swarms establish new nests, others can invade EHB colonies (Danka et al. 1992; Schneider et al. 2004b). During an invasion, the resident queen is often replaced by the Africanized queen in the swarm causing the EHB colony to become Africanized. Our study indicates that when AHB feed on EBB, they can attain hemolymph protein levels that are similar to those achieved by feeding on ABB. Interestingly, those protein levels are attained while consuming less EBB than ABB. The ability to efficiently use the food stored in the invaded colony increases the chances of its survival and thus could be a factor in the persistence of colony invasion behavior throughout the regions where AHB have immigrated.

Differences in protein uptake between EHB and AHB seem to be a function of the bee's metabolism 
rather than nutrient content or consumption rate of the bee bread itself. Those differences might be from environmental adaptations unique to where EHB and AHB originated. European bees are adapted to temperate climates and AHB to the tropics. In temperate areas, EHB have predictable patterns of resource availability and store excess food in their hives for periods of dearth (e.g., winter) (Seeley 1985). AHB are tropically adapted and have seasonal cycles of rapid colony expansion followed by swarming when resources are abundant and absconding when resources dwindle (McNally and Schneider 1992). Prior to absconding, workers consume all the brood and food stores in the nest (Schneider and McNally 1992b). Storing high concentrations of protein in their hemolymph would enable workers to carry more nutrients with them and perhaps begin rearing brood in their new nest prior to accumulating pollen stores. Indeed, during the establishment of new nests after absconding, African bees primarily raise brood and store little food (McNally and Schneider 1992). Differences between the environments where $\mathrm{EHB}$ and $\mathrm{AHB}$ originated might have resulted in different set points (i.e., homeostatic thresholds) for hemolymph protein concentrations much as they might have for vitellogenin levels (Amdam et al. 2005). The genetic structure responsible for establishing the vitellogenin set point has been instrumental in the evolution of the long-lived European "winter bee." Similar genetic structure might exist for establishing hemolymph protein levels in $\mathrm{AHB}$ to enable long range migration and nest reestablishment in the tropics. Future studies will be directed at determining if differences in hemolymph protein concentrations between EHB and AHB are due to genetic factors especially those regulating expression of proteolytic enzyme synthesis by the bees and/or their microbial symbionts (Anderson et al. 2011).

\section{ACKNOWLEDGMENTS}

The authors thank Mona Chambers, Geoffrey Hidalgo, and Maurissa Two Two for their technical assistance. We also thank Dr. Earl White for amino acid analysis, Dr. Roger Simonds for analysis of pollen for pesticides, and Drs. Stanley S. Schneider, Vanessa Corby-Harris, and Kirk Anderson for their reviews and discussion of earlier versions of the manuscript and many helpful suggestions.

Comparaison du pain d'abeille fabriqué par les abeilles africanisées et européennes (Apis mellifera) et ses effets sur la concentration en protéine de l'hémolymphe

Nutrition / microbes / protéine / acides aminés

Ein Vergleich des Bienenbrotes von Afrikanisierten und Europäischen (Apis mellifera) Honigbienen und dessen Effekt auf die Proteintiter in der Hämolymphe

\section{Ernährung / Mikroben / Protein / Aminosäuren}

Open Access This article is distributed under the terms of the Creative Commons Attribution License which permits any use, distribution, and reproduction in any medium, provided the original author(s) and the source are credited.

\section{REFERENCES}

Amdam, G.V., Norberg, K., Omholt, S.W., Kryger, P., Lourenço, A.P., Bitondi, M.M.G., Simões, Z.L.P. (2005) Higher vitellogenin concentrations in honey bee workers may be an adaptation to life in temperate climates. Insect. Soc. 52, 316-319

Anderson, K.E., Sheehan, T.H., Eckholm, B.J., Mott, B.M., DeGrandi-Hoffman, G. (2011) An emerging paradigm of colony health: microbial balance of the honey bee and hive (Apis mellifera). Insect. Soc. 58, 431-444

Becerra-Guzman, F., Guzman-Novoa, E., CorreaBenitez, A., Zozaya-Rubio, A. (2005) Length of life, age at first foraging and foraging life of Africanized and European honey bee (Apis mellifera) workers, during conditions of resource abundance. J. Apic. Res. 44, 151-156

Bertazzini, M., Medrzcki, P., Bortolotti, L., Maisrello, L., Forlani, G. (2010) Amino acid content and nectar choice by forager honeybees. Amino Acids 39, 315-318

Bonvehi, J.S., Jorda, R.E. (1997) Nutrient composition and microbiological quality of honeybee-collected pollen in Spain. J. Agric. Food Chem. 45, 725-732

Brodschneider, R., Crailsheim, K. (2010) Nutrition and health in honey bees. Apidologie 41, 278-294

Brosemer, R.W., Veerabhadrappa, P.S. (1965) Pathway of proline oxidation in insect flight muscle. Biochim. Biophys. Acta 110, 102-112 
Cappelari, F.A., Turcatto, A.P., Morais, M.M., DeJong, D. (2009) Africanized honey bees more efficiently convert protein diets into hemolymph protein than do Carniolan bee (Apis mellifera carnica). Genet. Mol. Res. 8, 1245-1249

Carter, C., Shafir, S., Yehonatan, L., Palmer, R.G., Thornburg, R. (2006) A novel role of proline in plant floral nectars. Naturwissenschaften 93, 72-79

Chevtchik V. (1950) Mikrobiologie pyloveho kvaseni. Publication from Faculty of Science, University of Masaryk, Czech Republic 323, 103-130

Collins, M.D., Lawson, P.A., Willems, A., Cordoba, J.J., Fernandez-Garayzabal, G.P., Cai, J., Hippe, H., Farrow, J.A. (1994) The phylogeny of the genus Clostridium: proposal of five new genera and eleven new species combinations. Int. J. Syst. Bacteriol. 44, 812-826

Crabtree, B., Newsholme, E.A. (1970) The activities of proline dehydrogenase, glutamate dehydrogenase, aspartate-oxoglutarate aminotransferase and alanine-oxoglutarate aminotransferase in some insect flight muscles. Biochem. J. 117, 1019-1021

Danka, R.G., Hellmich, R.L., Rinderer, T.E. (1992) Nest usurpation, supersedure and colony failure contribute to Africanization of commercially managed European honey bees in Venezuela. J. Apic. Res. 31, 119-123

Decanini, L.I., Collins, A.M., Evans, J.D. (2007) Variation and heritability in immune gene expression by diseased honeybees. J. Hered. 98, 195-201

DeGrandi-Hoffman, G., Wardell, G., Ahumada-Secura, F., Rinderer, T.E., Danka, R., Pettis, J. (2008) Comparisons of pollen substitute diets for honeybees: consumption rates by colonies and effects on brood and adult populations. J. Apic. Res. 47, 265270

Fewell, J.H., Bertram, S.M. (2002) Evidence for genetic variation in worker task performance by African and European honey bees. Behav. Ecol. Sociobiol. 52, 318-325

Field, A. (2005) Discovering Statistics using SPSS. Sage, Thousand Oaks, California, USA

Fonknechten, N., Chaussonnerie, S., Tricot, S., Lajus, A., Andreesen, J.R., Perchat, N., Pelletier, E., Gouuvenoux, M., Barbe, V., Salanoubat, M., LePaslier, D., Weissenbach, J., Cohen, G.N., Kreimeyer, A. (2010) Clostridium stricklandii, a specialist in amino acid degradation: revisiting metabolism through its genome sequence. BMC Genomics 11, 555

Gehrke, C.W., Leimer, K. (1971) Trimethylsilylation of amino acids derivatization and chromatography. J. Chromatogr. 57, 219-238

Gilliam, M. (1979a) Microbiology of pollen and bee bread: the genus Bacillus. Apidologie 10, 269-274

Gilliam, M. (1979b) Microbiology of pollen and bee bread: the yeasts. Apidologie 10, 43-53

Gilliam, M., Prest, D.B., Lorenz, B.J. (1989) Microbiology of pollen and bee bread: taxonomy and enzymology of moulds. Apidologie 20, 53-68
Harrison, J.F., Fewell, J.H., Anderson, K.E., Loper, G.M. (2006) Environmental physiology of the invasion of the Americas by Africanized honeybees. Integr. Comp. Biol. 46, 1110-1122

Hepburn, H.R., Reece, S.L., Neumann, P., Moritz, R.F.A., Radloff, S.E. (1999) Absconding in honeybees (Apis mellifera) in relation to queen status and mode of worker reproduction. Insect. Soc. 46, 323326

Human, H., Nicolson, S.W. (2006) Nutritional content of fresh, bee-collected and stored pollen of Aloe greatheadii var. davyana (Asphodelaceae). Phytochemistry 67, 1486-1492

Khachatryan, Z.A., Ktsoyan, Z.A., Manukyan, G.P., Kelly, D., Ghazaryan, K.A., Aminov, R.I. (2008) Predominant role of host genetics in controlling the composition of gut microbiota. PLoS One 3(8), e3064. doi:10.1371/journal.pone.0003064

Krajmalnik-Brown, R., Zehra-Esta, I., Dae-Wook, K., DiBlaise, J.K. (2012) Effects of gut microbes on nutrient absorptionand energy regulation. Nutr. Clin. Pract. 27, 201-214

Ley, R.E., Bäckhed, F., Turnbaugh, P., Lozupone, C.A., Knight, R.D., Gordon, J.I. (2005) Obesity alters gut microbial ecology. Proc. Natl. Acad. Sci. 102, 11070-11075

Ley, R.E., Peterson, D.A., Gordon, J.I. (2006) Ecological and evolutionary forces shaping microbial diversity in the human intestine. Cell 124, 837-848

Loper, G.M., Standifer, L.N., Thompson, M.J., Gilliam, M. (1980) Biochemistry and microbiology of beecollected almond (Prunus dulcis) pollen and bee bread. I. Fatty acids, sterols, vitamins, and minerals. Apidologie 11, 63-73

Mattila, H.R., Otis, G.W. (2006) Influence of pollen diet in spring on the development of the honey bee (Hymenoptera: Apidae) colonies. J. Econ. Entomol. 99, 604-613

McNally, L.C., Schneider, S.S. (1992) Seasonal cycles of growth, development, and movement of the African honey bee, Apis mellifera scutellata, in Africa. Insect. Soc. 39, 167-179

Metges, C.C. (2000) Contribution of microbial amino acids to amino acid homeostasis of the host. J. Nutr. 130, 1857S-1864S

Nielsen, D.I., Ebert, P.R., Page Jr., R.E., Hunt, G.J., Guzman-Novoa, E. (2000) Improved polymerase chain reaction-based mitochondrial genotype assay for identification of the Africanized honey bee (Hymenoptera: Apidae). Ann. Entomol. Soc. Am. 93, $1-6$

Rabe, M.J., Rosenstock, S.S., Nielsen, D.I. (2005) Feral Africanized honey bees (Apis mellifera) in Sonoran desert habitats of southwestern Arizona. Southwest. Nat. 50, 307-311

Rinderer, T.E., Buco, S.M., Rubink, W.L., Daly, H.V., Stelzer, J.A., Riggio, R.M., Baptista, F.C. (1993) Morphometric identification of Africanized and 
European honey bees using large reference population. Apidologie 24, 569-585

Roulston, T.H., Cane, J.H. (2000) Pollen nutritional content and digestibility for animals. Plant Syst. Evol. 222, 187-209

Sagili, R.R., Pankiw, T. (2007) Effects of proteinconstrained brood food on honey bee (Apis mellifera L.) pollen foraging and colony growth. Behav. Ecol. Sociobiol. 61, 1471-1478

Sagili, R.R., Pankiw, T., Zhu-Salzman, K. (2005) Effects of soybean trypsin inhibitor on hypopharyngeal gland protein content, total midgut protease activity and survival of the honey bee (Apis mellifera L.). J. Insect Physiol. 51, 953-957

Saltykova, E.S., Lvov, A.V., Ben'kovskaya, G.V., Poskryakov, A.V., Nikolenko, A.G. (2005) Interracial differences in expression of genes of antibacterial peptides, Abaecin, Hymenoptaecin, and Defensin, in bees Apis mellifera mellifera and Apis mellifera caucasica. J. Evol. Biochem. Phys. 41, 506-510

Schultz, D.J., Huang, Z.Y., Robinson, G.E. (1998) Effects of colony food shortage on behavioral development in honey bees. Behav. Ecol. Sociobiol. 42, 295-303

Schneider, S.S., McNally, L.C. (1992a) Factors influencing seasonal absconding in colonies of the African honey bee, Apis mellifera scutellata. Insect. Soc. 39, 402-423

Schneider, S.S., McNally, L.C. (1992b) Colony defense in the African honey bee in Africa (Hymenoptera: Apidae). Environ. Entomol. 21, 1362-1370

Schneider, S.S., McNally, L.C. (1993) Spatial foraging patterns and colony energy status in the African honey bee Apis mellifera scutellata. J. Insect Behav. 6, 195-210

Schneider, S.S., DeGrandi-Hoffman, G., Smith, D. (2004a) The African honeybee: factors contributing to a successful biological invasion. Annu. Rev. Entomol. 49, 351-376

Schneider, S.S., Deeby, T., Gilley, D.C., DeGrandiHoffman, G. (2004b) Seasonal nest usurpation of European colonies by African swarms in Arizona. U. S. A. Insect. Soc. 51, 359-364
Seeley, T.D. (1985) Honeybee Ecology. Princeton University Press, Princeton

Somerville D. (2005) Fat bees skinny bees - a manual on honey bee nutrition for beekeepers. RIRDC Publication No $05 / 054$

Spivak, M. (1992) The relative success of Africanized and European honey-bees over a range of life-zones in Costa Rica. J. Appl. Ecol. 29, 150-162

Spor, A., Koren, O., Ley, R. (2011) Unravelling the effects of the environment and host genotype on the gut microbiome. Nat. Rev. 9, 279-290

Standifer, L.N., McCaughey, W.F., Dixon, S.E., Gilliam, M., Loper, G.M. (1980) Biochemistry and microbiology of pollen collected by honey bees (Apis mellifera L.) from almond, Prunis dulcis. II. Protein, amino acids and enzymes. Apidologie 11, 163-171

Toth, A.L., Robinson, G.E. (2005) Worker nutrition and division of labour in honey bees. Anim. Behav. 69, 427-435

Toth, A.L., Kantarovich, S., Meisel, A.F., Robinson, G.E. (2005) Nutritional status influences socially regulated foraging ontogeny in honey bees. J. Exper. Biol. 208, 4641-4649

Turnbaugh, P.J., Ley, R.E., Mahowald, M.A., Magrini, V., Mardis, E.R., Gordon, J.I. (2006) An obesity associated gut microbiome with increased capacity for energy harvest. Nature 444, 1027-1031

Vasquez, A., Olofsson, T.C. (2009) The lactic acid bacteria involved in the production of bee pollen and bee bread. J. Apic. Res. 48, 189-195

Winston, M. (1992) The biology and management of Africanized honey bees. Annu. Rev. Entomol. 37, 173-193

Winston, M.L., Otis, G.W., Taylor, O.R. (1979) Absconding behavior of the Africanized honey bee in South America. J. Apic. Res. 18, 85-94

Woyke, J. (1976) Brood-rearing efficiency and absconding in Indian honeybees. J. Apic. Res. 15, 133-143

Woyke, J. (1977) Brood rearing and absconding of tropical honey bees. In: Fletcher, D.J.C. (ed.) African Bees, pp. 96-102. Apimondia, Pretoria 